\title{
A Critique of the Need and Application of Peace Education in Pakistan
}

\author{
Zahid Shahab Ahmed ${ }^{1}$
}

\begin{abstract}
Since the September 11 terrorist attacks in the United States, there has been greater interest in countering violent extremism. Due to the U.S.-led "War on Terror," madrassas in Pakistan have received international attention for initiating peace education programs through international NGOs. The motivation to work in madrassas is that erstwhile studies have blamed the madrassa education system for the lack of critical thinking and the vulnerability of madrassa students to extremist ideologies. While peace education interventions in Pakistan have continued for over a decade, there is a scarcity of scholarly assessments. This article aims to bridge that gap by analyzing the causes and consequences of extremism, particularly violent extremism in Pakistan, to make a case for and critically examine the application of peace education.
\end{abstract}

Keywords extremism, terrorism, Pakistan, peace education, NGOs

\section{Introduction}

While elsewhere peace education (PE) had established its roots through the works of prominent scholars in the field such as Elise Boulding, Johan Galtung, and Birgit Brock-Utne (Page 2008), it was introduced in Pakistan after the September 11 (henceforth 9/11) terrorist attacks in the United States. Thus, PE's evolution in Pakistan is largely a product of a sudden shift in international geopolitics after 9/11, and, compared to the development of this discipline elsewhere, PE was imported into Pakistan; and that too was not done under normal circumstances. It was a time when Pakistan was forced by the United States to join the "War on Terror." According to then the President of Pakistan General Pervez Musharraf, the Bush administration had "threatened to bomb Pakistan 'back to the stone age' after the September 11 attacks if the country did not cooperate with America's war on Afghanistan" (Goldenberg 2006).

Since 2001, the international community has devoted greater attention to 
promoting access to quality education that builds resilience against extremist ideologies. This is because radicalization is largely viewed as a function of social and political marginalization (Askerov 2010). After 9/11, leaders around the world, including then U.S. President George W. Bush, advocated eradicating terrorism through increased international aid and educational assistance. Others called for countering terrorism through poverty alleviation; however, there is only an indirect link identified between poverty and terrorism. A study reported that very poor people are less likely to support terrorism (Fair and Shepherd 2006). Another study reported the link between political conditions leading to marginalization and feelings of frustration in certain communities as causes of terrorism (Krueger and Malečková 2003). The globally concentrated effort on PE, or preventing violent extremism through education (PVE-E), has been largely focused on countries associated with rising violent extremism and militancy. Thus, international aid for PE/PVE-E focuses on countries known for sociopolitical circumstances conducive to the growth of extremist tendencies, for example, Afghanistan, Bangladesh, Indonesia, and Pakistan.

The focus of studies in peace research shifted to factors that lead to radicalization and violent extremism following the start of the "War on Terror." It is at this point that Pakistani madrassas (Islamic seminaries) came under the international spotlight for brainwashing the youth with prejudice and hatred against people of other sects and religions (Ahmed 2009; Ali 2009). According to Khokhar $(2007,353)$, the madrassas "located in Pakistan have played an important role in spreading militant jihadi ideologies." This global attention is responsible for millions of dollars of funding for PE projects in Pakistan. Early examples of PE in the country include nationwide workshops by the Washingtonbased International Centre for Religion and Diplomacy for madrassa teachers and administrators to promote religious tolerance, human rights, and critical thinking (ICRD 2018). This triggered a trend of PE efforts in madrassas across Pakistan-a tendency that remained monotonous for nearly a decade. Since its introduction in Pakistan, mainly due to the availability of international funding, $\mathrm{PE}$ has been growing and slowly has managed to divert attention to its need in public and private schools and out of school youth. Currently there are dozens of local organizations exclusively working on PE, such as the Peace Education and Development Foundation. ${ }^{2}$ In addition, several international organizations, for example, the United States Institute of Peace, have opened offices in Pakistan and have been supporting local PE initiatives.

For over a decade, there have been different kinds of PE programs at various levels, from primary to secondary schools, in Pakistan's three systems of education. In addition to madrassas, the country's education system includes 180,846 public and 80,057 private institutions (Hussain 2015). Despite the widespread reach of $\mathrm{PE}$, there little is known about their rationale, scope, and impact. The aim of this article is to bridge that gap through an examination of the 
selected PE programs. Data was collected in 2016 in the three largest provinces of Pakistan, i.e. Punjab, Sindh, and Khyber Pakhtunkhwa (KP), to prepare three case studies from each, nine in total. The selected projects have been implemented in madrassas as well as public and private schools. The organizations were selected based on their relevance, rapport, and strength of the PE curricula. The selected $\mathrm{PE}$ interventions were assessed in their particular contexts through face-toface interviews with the program team and participants, including students and teachers. As per the ethical requirements, this article only mentions the names of organizations and individuals who have given prior permission to be reported in this study. In terms of the organization of the article, the need of PE in Pakistan is discussed first, and followed by a section with key findings from the research.

\section{Peace Education: The Need}

Extremism and violent extremism are reflected in different forms across Pakistan. There are homegrown and external groups engaged in propagating hatred toward the so-called "others" and international terrorist organizations, such as Daesh, recruiting in Pakistan (Parvez 2016). Violent extremism has established roots and is reflected in the form of sectarian violence and regular attacks on non-Muslims. There are also structural reasons behind the marginalization of religious minorities. For this reason, the UK-based Minority Rights Group has put Pakistan eighth in the list of countries where minorities, particularly Shi'ites, Ahmadis, Hindus, and Christians, are under threat (Lattimer 2016, 208).

There are both domestic and geopolitical reasons for Pakistan's extremism problem. Created for the Muslims of the Indian Sub-continent, the role of Islam has been central to Pakistan's identity. Yet the process of Islamization started mainly in the 1970s and there was a sudden upsurge in that process during the 1980s. This was a crucial decade during which Pakistan joined a U.S.-led alliance to wage jihad against the Soviets in Afghanistan. The production of jihadis ${ }^{3}$ however involved the development of textbooks glorifying holy war against the so-called "Soviet infidels" (Ahmed 2012). While the war next door in Afghanistan ended in 1978, militant groups were largely left to their devices by their erstwhile partners, i.e. the United States and Pakistan. This led to the growth of such groups within Pakistan with spillover impacts across borders.

The impact of Islamization has been experienced beyond madrassas. Several studies have highlighted contents in public school textbooks that spread prejudice and hatred. From Aziz's (2004) The Murder of History to a co-authored study by Ahmed and Baxter (2007), there is evidence available that outlines how textbooks present factual errors, bias, and hate towards non-Muslims. This is a significant factor fueling the intolerance and extremism witnessed across Pakistan. The National Commission for Justice and Peace found that fifty-five 
Table 1. Terrorism-Related Fatalities in Pakistan by Region, 2011-2018

\begin{tabular}{c|c|c|c|c|c|c}
\hline \hline Punjab & Sindh & KP & Balochistan & FATA & GB & AJK \\
\hline 137 & 1,211 & 1,206 & 711 & 3,034 & 4 & 0 \\
\hline
\end{tabular}

Source: SATP 2018

chapters in twenty-two course books that are used in Sindh and Punjab contain discriminatory material against religious minorities (Express Tribune 2013). There has been research done on how education disseminators, teachers, and schools influence student behavior (Ahmed and Baxter 2007; de Talancé 2017). The case of Pakistan is complex because the problem is not only associated with pedagogies but also what is taught in schools. Based on this, a renowned Pakistani scholar Hoodbhoy $(2016,19)$ says: "Pakistani education explicitly rejects liberal objectives. Some variation exists across rich and poor schools, between villages and cities, and across provinces. However the basic road-map is provided by the school curriculum, textbooks, teachers, and examinations."

Pakistan has been a victim of terrorist attacks since 2002. The country has paid a heavy human and economic cost for terrorism; for example, through 2017, there were more than 67,000 terrorism-related casualties in Pakistan (Sabri 2017). For the period between 2002 and 2017, the Economic Survey of Pakistan estimated the economic cost of terrorism for the country to be US\$ 123.13 billion (GOP 2017, 280). Multiple factors, however, influence terrorism and related violence. For decades, Karachi, the capital of Sindh, has been a theatre of political and sectarian violence. There is an ongoing Baloch insurgency in Balochistan and security operations in the Federally Administered Tribal Areas (FATA). KP has also been experiencing regular terrorist attacks. Punjab, though peaceful in comparison to other regions, has still faced the repercussions of terrorism and religious extremism. In terms of terrorist attacks, FATA, Sindh, and KP are the three most affected regions of Pakistan (see Table 1). Following the start of the U.S.-led "War on Terror" in Afghanistan, Pakistan's FATA came under the international spotlight and since then this region has gone through several phases of violence caused by terrorism and counter-terrorism operations by the armed forces of Pakistan (Yamin and Malik 2014). While there has been significant progress in the "War on Terror" through the government of Pakistan's crackdown on terrorist elements, ${ }^{4}$ a permanent solution requires a comprehensive strategy to counter the effects of extremism.

The state has developed a national action plan for countering violent extremism (CVE) which has not been free from criticism (Yusuf 2016). The plan is limited in scope and does not go beyond madrassa reforms to a complete overhaul of the education system in Pakistan. To counter the effects of textbooks spreading hatred, there is a need to focus on nation-building-promoting a collective national or Pakistani identity that gives equal rights and protection to 
all citizens irrespective of their gender, religion, and ethnicity. This would be a step in a right direction to fulfil the premise of the Constitution of Pakistan. Here, integration of $\mathrm{PE}$ in the curricula can play a significant role. The education system serves as a central socialization agent besides providing knowledge, transferring values, symbols, norms, collective memories, attitudes, and perceptions from one generation to another (Vered 2014). "[PE] is considered a necessary element in establishing the social conditions required for promoting peace-making between rival parties" (ibid., 1). Former British Prime Minister Tony Blair has also advocated for cross-cultural education for countering terrorism, which according to him feeds on religious extremism (UN News 2013).

$\mathrm{PE}$ has received recognition the world over, especially through the United Nations (UN) and the United Nations Educational, Scientific and Cultural Organization (UNESCO) which has endorsed PE and sought to use its widespread reach to end violence and conflict through the promotion of a culture of peace. PE curriculums are designed based on a contextual analysis; therefore, they vary from place to place. It is time to include $\mathrm{PE}$ in the national action plan for CVE in Pakistan and, through its application, expand beyond the limited scope of projects run by NGOs. The focus on PE is important to build resilience against extremist ideologies among the vulnerable children in and out of schools. Considering the fact that Pakistan has three systems of education, there is a need to develop customized PE programs that address the needs of students in a particular system (Ahmed 2017).

\section{Peace Education: A Critique}

As mentioned earlier, Pakistani madrassas came under the international spotlight after $9 / 11$. This attracted much attention to the quality of curricula and teaching styles in madrassas and public schools. Initially, the focus of PE programs was limited to madrassas only, e.g. through earlier initiatives of the Washington-based International Center for Religion and Diplomacy. PE in Pakistan demonstrates a perfect case to understand the struggle of implementing organizations vis-àvis a balance between idealism and pragmatism. Given the context in which the education of wars is in the mainstream, for example through the glorification of war heroes in school textbooks, PE is merely limited to the realm of NGOs. The limited scope of PE is further constrained by the lack of capacity, implementation on ad hoc basis, irrelevant contents, shortage of quality teachers, domination of Western values, the absence of an NGO network, and the hostility of the government and extremist groups towards NGOs. ${ }^{5}$

It is a dilemma for the NGOs and their international donors to counter extremist ideologies through PE in Pakistan because their offices and workers are often attacked by extremist elements. Western approaches of peace and conflict 
are dominant in Pakistan's PE programs. The exported models largely focus on the implementation, development, and teaching of individual skills, such as interpersonal conflict management, mediation, and conflict resolution. However, Pakistan requires a collective approach rather than an individualistic Western approach. Studies done in other contexts have reported the limitations of Western approaches (Abu-Nimer 1996; Funk and Said 2004). Another issue with PE programs is the placement of teaching about wars in connection to peacemaking. None of the PE programs in Pakistan included topics relevant to wars, such as economic and human costs of wars with a comparison to the amount of financial investment in peacebuilding.

Idealistic thinking dominates the design and application of PE projects. The Community World Service has produced several PE books in Urdu, but has not made any efforts to promote those books for inclusion in the mainstream education system. Similar is the case of books being produced by the United Nations Children's Fund (UNICEF). An overwhelming majority of teachers interviewed by the author stressed the need of curriculum reforms to ensure the sustainability of PE.

Most of the short-term projects lack proper research and this leads to many PE projects being irrelevant to local realities. A major hurdle is to counter the influence of school textbooks promoting stereotyping and intolerance. There is, however, no NGO-run project that addresses this dimension. As mentioned above, evidence exists that points to how textbooks contain factual errors, biases, and hate material against non-Muslims (Aziz 2004; Ahmed and Baxter 2007). It is thus vital for PE programs to provide knowledge and skills to build resilience against extremist ideologies. Another challenge is to ensure that students retain the knowledge acquired from such programs and apply it in their lives. Due to interactive teaching styles, students in most of the PE projects retained knowledge on topics covered in those programs, such as peace, conflict, and conflict resolution. Nonetheless, PE programs should be long-term to ensure that students get regular opportunities to learn more and develop skills.

While there is no harm in aiming for an ideal society free from violence of any form, there is a need to be realistic and practical. Here the focus is again on the application of the PE knowledge with which we equip our students. The Charter for Compassion works in mainly private schools in Karachi, the biggest city of Pakistan, to teach compassionate skills as per the philosophy of Karen Armstrong (2011). Despite being a very innovative and creative program which is implemented by a young passionate team of trainers, the project does not teach students about relevant challenges; for example, are there times when showing compassion can get you in danger? For instance, how can students apply their compassionate skills, such as "courage," if a suicide bomber is attacking a place? The program in Pakistan teaches about the "dos" but not the "don'ts." Without this, students may limitedly or fail to apply the skills taught by the program. 
Are we giving students what they need? Do we conduct need assessments in classrooms before and during our training? Do we identify future peace leaders and stay engaged with them? Unfortunately, the answer to such questions is "no." This is mainly because PE projects are donor-driven, meaning not designed based on long-term engagement with neither a theme, a region, nor a target audience.

The threats of rampant religious extremism and terrorism compel the NGOs and their international partners to apply conflict-sensitive approaches in their projects. This pragmatic approach limits the scope of PE in many ways; for example, this restricts the programs to only areas that are relatively peaceful. There is another major limitation of the programs failing to target relevant groups, such as the ones directly vulnerable to extremist ideologies. An examination of the PE project of Jamia Naeemia, a madrassa based in Lahore, demonstrated a visible pragmatic approach in which the institute's administration decided to avoid the inclusion of sectarian (Shi'ite versus Sunni) fissure in the contents covered during the training. Here it is important to underline that madrassas are divided along on sectarian lines. Therefore, a Sunni madrassa cannot easily talk about the sectarian divide without getting into trouble, for instance through a clash with Shi'ite madrassas/militant groups and vice versa. Jamia Naeemia and its current leadership are meticulous because the institute's founding father, Mufti Sarfraz Ahmed Naeemi, who was famous for his views against terrorism and for the cause, was killed inside a madrassa by the Tehrik-i-Taliban terrorists in 2009 (Javed 2009). Thus, threats to personal life are real for many groups working to counter extremist ideologies in Pakistan.

The contents of PE programs manifest their limited scope. NGOs find it problematic to work with madrassas that openly consider issues such as tolerance, religious harmony, and human rights as Western values (Ahmed 2017). Due to these limitations, PE programs have reached a minor fraction of the country's 35,000 madrassas (Mansoor 2015). It is important to mention that only a minority of the total number of madrassas are engaged in extremist activities. However, the rest do suffer from problems due to the traditional mode of teaching and old contents. A madrassa teacher from Lahore revealed in an interview, "Islam and madrassas are wrongly linked to terrorism and militancy." Yet, he acknowledged, "some madrassas are established to spread extremism."

NGOs have been selecting their educational partners for PE programs based on convenience. This was the case of the majority of PE programs that mainly focused on the urban area madrassas due to the like-mindedness of their leadership and accessibility. NGOs have not approached madrassas where the traditional clerics tend to criticize modern technologies, such as the internet, as a Western instrument responsible for weakening Muslim culture and values. Nonetheless, many madrassas do not teach subjects on modern science and technology. It is partly a result of choice and limited resources (Ahmed 2009). Considering limited funding for peace, NGOs should focus on institutions, 
places, and groups that not just need their intervention but where they could introduce desired social/behavioral changes more effectively. Therefore, in many cases, PE has largely been about converting the converted. To reiterate, a key weakness of several projects was the lack of relevance to the local settings.

The avoidance of sensitive issues including inter-sectarian harmony is not typical to just madrassas because PE programs across the board have not moved beyond a fixed set of issues, e.g. interfaith harmony, a basic understanding of conflict resolution, human rights and peace, and the concept of peace in Islam. None of the examined projects focused on disarmament, environmental security, and structural violence. Peace educators the world over have stressed the need of including these topics in PE (Reardon 1978; Stapp 1978). The omission of such important themes cannot be labeled as being pragmatic because various NGOs lack the capacity to produce, based on solid research, relevant PE contents. Due to the availability of foreign aid, several NGOs claim to have expertise in PE, but in reality they do not have the capacity to do it full justice. Without naming the organization, an interesting case is an organization, which claimed to have substantial experience in $\mathrm{PE}$, decided to outsource the development of $\mathrm{PE}$ material to a third party. It is no surprise that the outcome was a disaster.

Besides avoiding contentious issues, PE NGOs in Pakistan have also been practical and creative in their selection of project titles. The use of the word "peace" carries negative connotations in Pakistan. There is a widespread perception that such programs are a part of Western propaganda against Islam and Pakistan. To counter this perception and to gain legitimacy, many NGOs have developed PE material based on Islamic teachings. The prominent examples are of the books produced on Islam and conflict resolution/peace by the United States Institute of Peace and the Peace and Education Foundation (Qamar-ul-Huda 2010; Ahmed et al. 2015). An important aspect of the methodology behind the mentioned books was the involvement and endorsement of prominent Muslim scholars. This strategy has worked for the NGOs working with a wide range of actors, especially madrassas. Prominent examples are that of Jamia Naeemi and the Peace and Education Development (PEAD) Foundation who have developed programs with the key principle that peace and conflict resolution should be presented as inherently Islamic values. This has definitely helped the implementing organizations in developing a good rapport with the target communities. Also, as mentioned above, NGOs have been hesitant to use the word "peace" in the titles of their programs; for example, a teaching peace project of the PEAD Foundation is entitled the "Strengthening Social Cohesion and Resilience through Education Initiative." This particular concern about the negative perceptions of "peace" is more prevalent in madrassas.

The success of any educational project rests on the quality of teachers. A study conducted in Pakistan found a correlation between teacher quality and student achievement (de Talancé 2017). As explored in this research, several PE 
programs lacked quality teachers. Teachers of many programs were not trained and, therefore, were incapable of imparting key skills such as critical thinking. In addition, PE programs focused on teacher training were only partially successful because of the limited capacity of trainers and the short-term nature of interventions. Considering the fact that teachers in madrassas and public schools are not highly educated and trained (Ahmed 2017), there is a need for longerterm interventions to introduce teachers to theories and practices relevant to teaching in general and PE in particular.

Considering the sensitivities linked to working in Pakistan, non-state actors have to be extra cautious. There is an unwritten agreement between the donors and the local NGOs to refrain from publicizing the names of donors, often from the West, in their project material. Considering the presence of violent religious extremism across Pakistan, this is a pragmatic approach. Organizations in conflict-affected areas, particularly in KP, did not advertise that their work was funded by foreign organizations because disclosure could have severe security repercussions. According to a report, Pakistan remains one of the deadliest countries for aid workers (Sheikh 2015). There have been regular incidents of violent attacks on NGOs; for example, there was an attack on a World Vision office in 2010 that killed six people (BBC 2010). In Swat, which was under the control of the local Taliban during 2007-2009, Swat Youth Front did not disclose the name of its donor (Institute of War and Peace Reporting, United Kingdom). This also means that the representatives of international donor organizations cannot visit project sites, which on one hand raises concerns about monitoring and evaluations, but on the other hand it was also not feasible for security reasons. Often, visits from donor organizations, including Western team members, to project areas in rural Pakistan create difficulties for the local partner organizations. Nonetheless, NGOs with a larger canvas could share information about their well-established donors, e.g. the UN and the European Union.

$\mathrm{PE}$ in practice is heavily dependent on critical thinking pedagogies and the transfer of skills to equip students with better abilities to resolve conflicts (Harris 2004). In the context of Pakistan, PE is needed to provide students and teachers with knowledge and thinking to counter extremist ideologies. Thus, PE is also about countering/preventing violent extremism. Here it is important to talk about the work of the Swat Youth Front. Through the organization's program, students were encouraged to write on issues such as human rights, women's rights in Islam, post-conflict reconstruction, and contemporary socio-political issues in a magazine called Naveed-e-Sahar. This initiative helped develop students' knowledge on critical issues and writing as well as information-sharing skills.

There are examples of initiatives being inspired by international PE approaches. The Grammar School Rawalpindi (GSR) is a private school that has modelled its PE classes on UNESCO's guidelines. GSR teachers have been discussing the progressive phase of Muslims, such as times when Muslims were 
scientifically more advanced that the rest of the world, to counter the glorification of wars that is prevalent in the government-endorsed textbooks. A teacher from GSR stated that PE is difficult to promote when the realities outside the classroom are unconducive to the PE taught on an ad hoc basis for about an hour every week. Teachers from GSR also said that the new media, especially social media, exposes students to negative ideologies that their limited PE model does not address.

Among the successful cases is the initiative of the Paiman Alumni Trust, henceforth Paiman. This organization runs PE projects in Peshawar to train teachers and students at two local private schools through an integrated approach (Ahmed 2017). In this model, PE is included in the regular primary and secondary level curricula. Students were interviewed from a participating school and they reflected a clear understanding of the concepts of peace and conflict by linking key features of the learning to the notions of justice, development, and security. This level of understanding of peace and security was not observed among students of other projects that were implemented on ad hoc basis, meaning not integrated into the regular education. Paiman has an idealistic approach to present this project as a model to mainstream PE in other schools, but this is unlikely to happen unless the government authorities are convinced to mainstream PE as part of a long-term strategy to prevent/counter violent extremism in Pakistan.

Despite the remarkable growth of the peacebuilding sector in Pakistan since 2002, there is no forum or network that could bring various PE individuals and organizations together. This is due to several reasons such as competition among NGOs with divergent interests. The lack of networking among the NGOs poses serious threats to their own survival when there is an ongoing governmental crackdown on the local and international NGOs. Also, this leads to a waste of energy and resources due to the absence of mechanisms through which knowledge and expertise could be shared instead of reinventing the wheel by producing similar PE contents. Working jointly would also help in strengthening advocacy for inclusion of PE in the three systems of education.

The field of PE is underdeveloped in Pakistan. The case of PE NGOs in Pakistan is a mixed bag of successes and failures, and demonstrates their struggle to maintain a balance between idealism and pragmatism. While some aim for the stars in terms of teaching for an ideal peaceful society, others miss the mark by teaching irrelevant contents. Many implementing organizations lack the capacity to produce contextualized contents. This limitation was reflected through poor implementation, monitoring, and evaluation in several programs. PE organizations navigate in a highly sensitive territory in which a slight mistake can lead to disastrous consequences, for example through direct attacks by violent extremist groups. This phenomenon is aggravated by the government's protection of extremist groups and a governmental crackdown on NGOs. Thus, the local 
NGOs work very carefully, avoiding the risk of entering regions they ideally should not and producing the contents that they ideally should promote. Despite all these challenges, $\mathrm{PE}$ is vital to prevent/counter violent extremist ideologies in Pakistan. One of the constraints to PE in Pakistan is the prevalence of the three systems of education in which each system has limited or no interaction with the other. This ultimately demands customized programs to address the needs of each separate system.

\section{Conclusion}

The plight of Pakistan's education system is no longer a hidden reality. The three systems of education catering to the needs of students primarily belonging to different socio-economic classes continue to divide the country which is already divided on religious and ethnic lines. Adding to this complexity are the prevalent challenges of violent extremism. While PE is not a solution to all of this, it is at least an option to build resilience against extremist ideologies that are being promoted by home-grown and foreign groups. As the threat of extremism is not just limited to madrassas, there is an urgent need to expand the scope of PE to students in public and private schools in urban and rural areas. As explored in this study, PE programs are largely limited to urban areas. Even in the case of madrassas, PE programs have not been able to deal with the most important challenges facing Pakistan, such as the sectarian violence. There is a lot of hesitation among madrassa administrations to talk about inter-sectarian harmony. While greater efforts have been made to develop and translate into local languages contents on Islam and peace, there is a need to go beyond religion to cultural aspects, such as Sufism and traditional mechanisms of conflict resolution, in PE curricula.

Across the board, students of all programs were found to have retained most of the information provided through the examined PE programs. This is despite the fact that the quality of teachers was not the same, but projects having good quality teachers, such as in the cases of GSR and Paiman, were found to have better results. The PE organizations studied for this research are trying to achieve what they can with limited funding and training. Due to the widespread reach of radicalization and extremist organizations, the $\mathrm{PE}$ groups in Pakistan have to adapt to existing realities by being pragmatic. A governmental crackdown on NGOs began in 2011, forcing these institutions to face an existential threat. To overcome the range of challenges listed in this article, it is proposed that PE organizations create mechanisms, such as a network, which could assist with more organized advocacy for the integration of PE in school curricula at all levels. Such a network could also be useful in transferring PE knowledge. 


\section{Notes}

1. This article is based on the author's extensive research of peace education in Pakistan. The author has written permission from the mentioned organizations to cite their work. The United States Institute of Peace, Washington, funded this research.

2. For more information about peace education organizations in Pakistan visit: https:// www.peaceinsight.org/conflicts/pakistan/.

3. Jihad is a complex term that has multiple meanings; for example, it means a struggle or fight against the enemies of Islam and, also, a personal/spiritual struggle within oneself against sin.

4. While reporting a decline in terrorism in Pakistan, Global Terrorism Index 2017 ranked Pakistan at number five (IEP 2017, 10).

5. In December 2017, the government of Pakistan gave notice to twenty-seven NGOs, including Plan International, Oxfam Novib, World Vision, and Action Aid, to close their operations in Pakistan. This is a continuation of the government's crackdown following the killing of Osama bin Laden in Pakistan in 2011. It is reported that Save the Children had organized a polio vaccination campaign to provide information on bin Laden to the CIA (Sayeed 2017).

\section{References}

Abu-Nimer, Mohammed. 1996. "Conflict resolution in an Islamic context: Some conceptual questions." Peace \& Change 21 (1): 22-40.

Ahmed, Niaz, Muhammad Hanif, Azhar Hussain, and Rashad Bukhari. 2015. Peace Education and Islam. Islamabad: Peace and Education Foundation.

Ahmed, Zahid Shahab. 2009. "Madrasa education in the Pakistani context: Challenges, reforms and future directions." Peace Prints: South Asian Journal of Peacebuilding 2 (1): 53-65.

Ahmed, Zahid Shahab. 2012. "Political Islam, the Jamaat-e-Islami, and Pakistan's role in the Afghan-Soviet War, 1979-1988." In Religion and the Cold War: A Global Perspective, ed. Philip E. Muehlenbeck, 275-298. Nashville: Vanderbilt University Press.

Ahmed, Zahid Shahab. 2017. "Peace education in Pakistan." United States Institute of Peace, March 3. https://www.usip.org/sites/default/files/2017-03/sr-400-peaceeducation-in-pakistan.pdf (accessed May 9, 2018).

Ahmed, Zahid Shahab, and Michele A. Baxter. 2007. Attitudes of Teachers in India and Pakistan: Texts and Contexts. New Delhi: WISCOMP.

Ali, Saleem H. 2009. Islam and Education: Conflict and Conformity in Pakistan. Karachi: Oxford University Press.

Armstrong, Karen. 2011. Twelve Steps to a Compassionate Life. London: Random House.

Askerov, Ali. 2010. "Peace education and conflict resolution: A critical review." Innovative Issues and Approaches in Social Sciences 3 (1): 5-35.

Aziz, K. K. 2004. The Murder of History: A Critique of History Textbooks Used in Pakistan. Lahore: Sang-e-Meel Publishers.

BBC. 2010. "Six killed in attack on World Vision office in Pakistan." March 10. http://news. 
bbc.co.uk/2/hi/south_asia/8559078.stm (accessed June 5, 2017).

de Talancé, Marine. 2017. "Better teachers, better results? Evidence from rural Pakistan." The Journal of Development Studies 53 (10): 1697-1713.

Express Tribune. 2013. "Study reflects school textbooks need to be free of religious discrimination.” May 26. https://tribune.com.pk/story/554318/study-reflects-schooltextbooks-need-to-be-free-of-religious-discrimination/ (accessed June 5, 2017).

Fair, C. Christine, and Bryan Shepherd. 2006. "Who supports terrorism? Evidence from fourteen Muslim countries." Studies in Conflict \& Terrorism 29 (1): 51-74.

Funk, Nathan C., and Abdul Aziz Said. 2004. "Islam and the West: Narratives of conflict and conflict transformation." International Jouranl of Peace Studies 9 (1): 1-28.

Goldenberg, Suzanne. 2006. "Bush threatened to bomb Pakistan, says Musharraf." The Guardian, September 22. https://www.theguardian.com/world/2006/sep/22/pakistan. usa (accessed October 10, 2017).

GOP (Government of Pakistan). 2017. Economic Suvey of Pakistan 2016-17. Islamabad: Ministry of Finance, Government of Pakistan.

Harris, Ian M. 2004. "Peace education theory." Journal of Peace Education 1 (1): 5-20.

Hoodbhoy, Pervez. 2016. "How Pakistan's education radicalizes?” Development Advocate Pakistan 3 (1): 19-20.

Hussain, Aftab. 2015. "Education system of Pakistan: Issues, problems and solutions." Islamabad Policy Research Institute. http://www.ipripak.org/education-system-ofpakistan-issues-problems-and-solutions/ (accessed April 18, 2018).

ICRD (International Centre for Religion and Diplomacy). 2018. "Religious education in Pakistan.” Accessed May 9. https://icrd.org/programs/asia/pakistan/.

IEP (Institute for Economics and Peace). 2017. Global Terrorism Index 2017. https:// reliefweb.int/sites/reliefweb.int/files/resources/Global\%20Terrorism\%20Index\%20 2017\%20\%284\%29.pdf (accessed May 9, 2018).

Javed, Ashraf. 2009. "Sarfraz Naeemi killed in suicide hit." The Nation, June 13. https:// nation.com.pk/13-Jun-2009/sarfraz-naeemi-killed-in-suicide-hit (accessed November 10, 2017).

Khokhar, Moniza. 2007. "Reforming militant Madaris in Pakistan." Studies in Conflict \& Terrorism 30 (4): 353-365.

Krueger, Alan B., and Jitka Malečková. 2003. "Education, poverty and terrorism: Is there a causal connection?” Journal of Economic Perspectives 17 (4): 119-144.

Lattimer, Mark. 2016. "Peoples under threat 2016." In State of the World's Minorities and Indigenous Peoples 20161, ed. Peter Grant, 204-217. London: Minority Rights Group International.

Mansoor, Hasan. 2015. “Report on state of Madressahs in Pakistan launched.” Dawn, July 31. https://www.dawn.com/news/1197466 (accessed October 2, 2017).

Page, James. 2008. Peace Education: Exploring Ethical and Philosophical Foundations. Charlotte: Information Age Publishing.

Parvez, Tariq. 2016. "The Islamic state in Pakistan.” United States Institute of Peace, September 21. https://www.usip.org/publications/2016/09/islamic-state-pakistan (accessed May 9, 2018).

Qamar-ul-Huda. 2010. Crescent and Dove: Peace and Conflict Resolution in Islam. Washington: USIP Press.

Reardon, Betty. 1978. “Disarmament and peace education." Prospects 8 (4): 395-405. 
Sabri, Farid. 2017. “67,399 people killed in terror attacks during past 15 years." Pakistan Times, May 20. https://www.pakistantoday.com.pk/2017/05/20/67399-people-killedin-terror-attacks-during-past-15-years/ (accessed August 14, 2017).

SATP (South Asia Terrorism Portal). 2018. "Fatalities in Pakistan region wise: 2011-2018." Accessed March 2. http://satp.org/Datasheets.aspx?countries=pakistan.

Sayeed, Saad. 2017. "Pakistan closes 27 NGOs in what activists see as widening crackdown." Reuters, December 22. https://www.reuters.com/article/us-pakistan-rights/pakistancloses-27-ngos-in-what-activists-see-as-widening-crackdown-idUSKBN1EG0SJ (accessed Sepember 25, 2017).

Sheikh, Ismail. 2015. "Pakistan remains one of the deadliest countries for aid workers: Report." The Express Tribune, July 16. https://tribune.com.pk/story/921696/pakistanremains-one-of-the-deadliest-countries-for-aid-workers-report/ (accessed March 20, 2018).

Stapp, William B. 1978. "An instrumental model for environmental education." Prospects 8 (4): 495-507.

UN (United Nations) News. 2013. “Terrorism can only be defeated by education, former British leader Blair tells UN.” November 21. https://news.un.org/en/story/ 2013/11/455992-terrorism-can-only-be-defeated-education-former-british-leaderblair-tells-un\#.VL_rJS5rLDc (accessed September 5, 2017).

Vered, Soli. 2014. "Peace education in Israel: An educational goal in the test of reality." Journal of Peace Education: 1-16.

Yamin, Saira, and Salma Malik. 2014. "Mapping conflict trends in Pakistan." United States Institute of Peace, February 7. https://www.usip.org/publications/2014/02/mappingconflict-trends-pakistan (accessed May 9, 2018).

Yusuf, Moeed. 2016. "Not really a plan.” Dawn, September 13. https://www.dawn.com/ news/1283790/not-really-a-plan (accessed April 2, 2018).

Zahid Shahab Ahmed (Ph.D.) is a Research Fellow at Alfred Deakin Institute for Citizenship and Globalization, Deakin University, Australia. During 2013-2016, he was an Assistant Professor of Peace and Conflict Studies at the Centre for International Peace and Stability, National University of Sciences and Technology in Pakistan. E-mail: zahid.ahmed@deakin.edu.au. 